\title{
INTEGRATED WASTEWATER MANAGEMENT ON A COUNTY BASIS
}

\section{A. TZIMAS \\ E. GAVALAKI \\ A. ANDREADAKIS*}

Selected from papers presented at the $7^{\text {th }}$ Conference on Environmental Science and Technology, 3-6 September 2001, Ermoupolis, Syros island, Greece.
Sanitary Engineering Laboratory,
Department of Water Resources Hydraulics and Maritime Works,
School of Civil Engineering,
National Technical University of Athens
5, Iroon Polytechneiou street, Zografou 15773, Athens

*to whom all correspondence should be addressed: fax: + (30) 2106528078, 2107722899

e-mail: andre1@central.ntua.gr

\begin{abstract}
The paper discusses a methodology for integrated municipal wastewater management. In compliance to the EU Directive 91/271, there is a legal binding to ensure that all agglomerations with populations over 2000 are provided with wastewater collecting system and adequate treatment. The conditions for optimum application of the Directive in Greece, especially in the light of the recent administrative reorganization, and the management of small rural communities not covered by the Directive are addressed, with reference to a case study application in the Achaia County. In compliance to the EU Directive 91/271, it is estimated that collecting systems and treatment should expand to at least $70 \%$ of the total population. However, due to the expanding touristic activity, the limited availability of land, environmental considerations, and favorable population characteristics (high density, relatively large communities) and morphological and socioeconomical conditions, it is proposed that coverage can reach to $85 \%$ of the total population. As for the rest of the County population (15\%), decentralized on site wastewater treatment and disposal schemes were proved to be the most technically effective and economically efficient alternative.
\end{abstract}

KEYWORDS: Wastewater management, Directive 91/271, decentralized systems, on site treatment

\section{INTRODUCTION}

The introduction of the 91/272/EEC Directive, concerning urban wastewater treatment and the reorganization of the administrative structure pursued with the National Law 2539/97, also known as "Kapodistrias Law", set out the basis for a comprehensive evaluation of the local needs and priorities regarding wastewater collection and treatment and a decentralized planning process.

One of the major parameters that has to be taken into consideration is the requirements that stem from the National and European Community legislative framework. The EU Directive 91/271 (EC, 1991) and the Ministerial Decree $5673 / 400 / 97$ (MD, 1997) define the level of treatment and the required schedule of compliance according to the size of the agglomerations and the nature of the receiving body. The EU member states, among them Greece, have to ensure that all agglomerations with a p.e. of more than 2000 
Table 1. Wastewater treatment plants in Achaia County (as of 2000)

\begin{tabular}{|c|c|c|c|c|c|c|}
\hline \multirow[t]{2}{*}{$\mathbf{a} / \mathbf{a}$} & \multirow[t]{2}{*}{ WWTP } & \multirow[t]{2}{*}{ Municipality } & \multirow{2}{*}{$\begin{array}{l}\text { Type of } \\
\text { Wastewater }\end{array}$} & \multicolumn{2}{|c|}{ Population served } & \multirow{2}{*}{$\begin{array}{l}\text { Receiving } \\
\text { Body }\end{array}$} \\
\hline & & & & Population & Percentage & \\
\hline 1 & Kato Achaia & Dymi & Municipal & 5297 & 1,64 & Patraikos Gulf \\
\hline 2 & Erimanthia & Tritaia & $\begin{array}{l}\text { Municipal- } \\
\text { industrial }\end{array}$ & 175 & 0,05 & Kalipaki Stream \\
\hline 3 & Klitoria & Leykasio & Municipal & 865 & 0,27 & Aroanios River \\
\hline 4 & $\begin{array}{l}\text { University } \\
\text { of Patras }\end{array}$ & Rio & $\begin{array}{l}\text { Hospital - } \\
\text { Municipal }\end{array}$ & - & - & Patraikos Gulf \\
\hline 5 & $\begin{array}{l}\text { Industrial } \\
\text { District }\end{array}$ & Olenia & $\begin{array}{l}\text { Industrial - } \\
\text { seepage }\end{array}$ & - & - & Patraikos Gulf \\
\hline 6 & Patra & Patra & Municipal & $-*$ & -* & Patraikos Gulf \\
\hline 7 & Egio & Egio & Municipal & $-*$ & -* $^{*}$ & Korinthiakos G. \\
\hline \multicolumn{4}{|c|}{ Total Achaia County } & 6337 & 1,96 & \\
\hline
\end{tabular}

(*) WWTP under construction

are provided with collecting systems for urban wastewater and the wastewater entering the collecting systems shall before discharge be subject to adequate treatment at the latest by 31 December 2005 for those with p.e between 2.000 and 15.000 and 31 December 2000 for those with p.e. of more than 15.000 , with the following characteristics:

$\begin{array}{lccc} & \text { BOD }_{5} & \text { COD } & \text { TSS } \\ \text { Limit, mg 1-1 } & 25 & 125 & 35-60 \\ \text { Removal,\% } & 70-90 & 75 & 90-70\end{array}$

For sensitive areas the Directive requires more advanced than secondary treatment with discharge requirements $10-15^{2} \mathrm{mg} \mathrm{l}^{-1}$ for total nitrogen and $1-2^{2} \mathrm{mg} \mathrm{l}^{-1}$ for total phosphorus, depending on size of the plant.

\section{THE CASE OF ACHAIA COUNTY Survey results}

The County of Achaia is located at the NW part of Peloponissos and due to its geographical position, retains a significant politico-economical interest. Its permanent population, according to the 1991 census, is 300.078 , which is distributed administratively into 23 municipalities (National Law, 1997).

Most of the permanent (about $80 \%$ ) population is gathered on the costal front of the County and particularly around the urban and semi-urban communities of the region, such as the city of Patra, Egio and Kato Achaia.

The pattern of population change (census data from 1951 to 1991), indicated an internal immi- gration towards the N-NW regions of the County. The population projections indicated that for the year 2000, 12 out of 13 communities with population between 2.000 and 15.000 (Aigira, Akrata, Diakofto, Rododafni, Agios Vasilios, Rio, Paralia, Saravali, Ovria, Vrahneika, Kato Achaia and Sageika) and the 2 cities (Patra and Egio) with population of more than 15.000 , for which there is a legal obligation to provide for wastewater collecting system and treatment facilities are situated on the costal zone. The picture is similar regarding the distribution of the seasonal population since $86 \%$ of the total hotel capacity is located in the NW costal area of the County.

The survey that was carried out in the region demonstrated that of the 262.000 population that reside on the costal front of the County, only $2 \%$ (5.300 inhabitants) is served by wastewater collecting system and treatment, $62 \%$ of the population (163.296 inhabitants related mainly in the municipalities of Patra and Egio), is served only by wastewater collecting systems without any treatment and the rest 36\% (93.419 inhabitants) uses septic tanks (Tables 1, 2). However it is noted that the WWTP of Patra and Egio are in the final phase of construction. With these WWTP operating, it is anticipated that almost $50 \%$ of the total County population (160.500) will be served by collecting system and adequate treatment.

The accumulation of population (regular and seasonal) on the costal area of the County results in the production of significant pollution loads of municipal origin, the greatest extent of which is discharged without treatment into the Patraikos 
Table 2. Collecting system coverage for each municipality (as of 2000)

\begin{tabular}{|c|c|c|c|c|c|c|c|}
\hline \multirow[t]{2}{*}{$\mathbf{a} / \mathbf{a}$} & \multirow[t]{2}{*}{ Municipality } & \multicolumn{3}{|c|}{ Coverage } & \multicolumn{3}{|c|}{ Served population } \\
\hline & & $\begin{array}{c}\text { Combined } \\
\%\end{array}$ & $\begin{array}{c}\text { Separate } \\
\%\end{array}$ & $\begin{array}{c}\text { Total } \\
\%\end{array}$ & Population & $\begin{array}{c}\text { Municipality } \\
\%\end{array}$ & $\begin{array}{c}\text { County } \\
\%\end{array}$ \\
\hline 1 & Aigira & - & - & - & 0 & 0 & 0 \\
\hline 2 & Akrata & - & - & - & 0 & 0 & 0 \\
\hline 3 & $\begin{array}{l}\text { Diakofto } \\
\text { Egio }\end{array}$ & 10 & - & 10 & 778 & 10,0 & 0,24 \\
\hline \multirow[t]{2}{*}{4} & Egio & 60 & 0 & 60 & 14125 & 46,9 & 4,38 \\
\hline & Kouloura & 0 & 100 & 100 & $0^{*}$ & 0 & 0 \\
\hline 5 & Sympolitia & - & - & - & 0 & 0 & 0 \\
\hline 6 & ErineosDamakinio & 100 & 0 & 100 & 114 & 2,9 & 0,04 \\
\hline 7 & Rio & - & - & - & 0 & 0 & 0 \\
\hline \multirow[t]{2}{*}{8} & Patra & 60 & 20 & 80 & 130726 & 78,7 & 40,54 \\
\hline & $\begin{array}{l}\text { Patra } \\
\text { Messatida }\end{array}$ & & & & & & \\
\hline \multirow[t]{3}{*}{9} & Ovria & 80 & 0 & 80 & 4310 & 34,3 & 1,34 \\
\hline & Kalithea & 40 & 0 & 40 & $0^{*}$ & 0 & 0 \\
\hline & Saravali & 45 & 0 & 40 & $0^{*}$ & 0 & 0 \\
\hline \multirow[t]{2}{*}{10} & Paralia & 0 & 30 & 30 & $0^{*}$ & 0 & 0 \\
\hline & Paralia & & & & & & \\
\hline 11 & Vrachneika & - & - & - & 0 & 0 & 0 \\
\hline \multirow[t]{2}{*}{12} & Dymi & & & & & & \\
\hline & Kato Achaia & 30 & 70 & 100 & 5297 & 59,0 & 1,64 \\
\hline 13 & Fares & - & - & - & 0 & 0 & 0 \\
\hline \multirow[t]{3}{*}{14} & Olenia & & & & & & \\
\hline & Fostena & 100 & 0 & 100 & 264 & 3,8 & 0,08 \\
\hline & Mazaraki & 100 & 0 & 100 & $0^{*}$ & 0 & 0 \\
\hline 15 & Movri & - & - & - & 0 & 0 & 0 \\
\hline 16 & Larissos & - & - & - & 0 & 0 & 0 \\
\hline \multirow[t]{2}{*}{17} & Tritaia & & & & & & \\
\hline & Erimanthia & 0 & 100 & 100 & 175 & 3,6 & 0,05 \\
\hline \multirow[t]{2}{*}{18} & Leykasio & & & & & & \\
\hline & Klitoria & 0 & 100 & 100 & 865 & 25,8 & 0,27 \\
\hline \multirow[t]{2}{*}{19} & Kalavrita & & & & & & \\
\hline & Kalavrita & 30 & 0 & 30 & 736 & 9,0 & 0,23 \\
\hline 20 & Aroania & - & - & - & 0 & 0 & 0 \\
\hline \multirow[t]{2}{*}{21} & Paion & & & & & & \\
\hline & Dafni & 0 & 100 & 100 & 1374 & 58,9 & 0,43 \\
\hline 22 & Kalentzio & - & - & - & 0 & 0 & 0 \\
\hline \multirow[t]{2}{*}{23} & Leontio & & & & & & \\
\hline & Leontio & 100 & 0 & 100 & 389 & 62,4 & 0,12 \\
\hline Total & Achaia County & 37,4 & 12,0 & 49,4 & 147139 & - & 49,35 \\
\hline
\end{tabular}

(*) The wastewater collecting system is not operational

and Korinthiakos Gulfs. The seasonal stratification that occurs along the southern part of Patraikos Gulf during the summer reduces its assimilating capability with a negative impact on its quality (Zacharias et al., 1995; Lazarou et al., 1999). Given the importance of the marine ecosystems of the Patraikos and Korinthiakos Gulfs in the ecology and the economy of the County due to their amenity, fishing and commercial value, their quality deterioration impedes with the growth prospects of the County. Moreover the aquifers in the costal zone of the County are deployed on sand and gravel depositions, which are characterized by high permeability and low infiltration time through the unsaturated zone that in turn makes them particularly vulnerable to pollution (Rozos, 
1989). Considering that a large part of the water demand for all types of uses (potable water, irrigation, industrial uses) in the costal area is met by groundwater (Krestenitis et al., 1999), water quality impediment does not only relate to economical considerations but to direct public health dangers. The characteristics of the environment differentiate drastically in the inland part of the County. From demographic point of view, the only substantial municipal clusters is the town of Kalavrita and to a lesser extent the villages Halandritsa and Dafni. Most of the other communities have populations that do not exceed 500 inhabitants and they are characterized by relatively low density and mountainous and semi-mountainous morphology.

\section{Suggestions for integrated municipal wastewater management}

It becomes evident that from the point of view of environmental pressures and consequently necessary pollution prevention measures, the County is divided into two sub-regions with different characteristics.

The first sub-region that constitutes mainly the coastal front of the County, is characterized by a relatively high population density, intense touristic activity and several urban residential centers with significant population.

Due to this general characteristics the following factors, influencing wastewater collection and treatment, should be addressed:

- Land is rather scarce and expensive

- Reluctancy towards allocating sites for treatment plants is intensified

- The two gulfs (Patraikos and Korinthiakos) being the recipients of the treated sewage create the need for construction of outfalls for each treatment facility, thus increasing capital costs

- The high amenity value of the coastal zone created the need for advanced and reliable treatment, a goal difficult to achieve at a small scale level, at least by conventional systems

- Due to the characteristics of the aquifers, adoption of on site systems, often used in conjunction with subsurface disposal, is problematic

- Land scarcity and fairly high population densities practically prohibit the application of alternative systems requiring relatively large areas, (e.g. wetlands or ponds).

On the basis of these considerations it seems prudent to apply the concept of centralized treatment over the whole coastal front. Adopting this rationale, it is suggested that wastewater collection systems are extended to cover even small communities, which are not obliged by the provisions of the Directive to be served by a sewerage system. Furthermore, recognizing the difficulties associated with locating new treatment facilities, it is recommended to exploit to the maximum the capacity of the existing treatment plants, or even upgrade and expand them. It is therefore proposed that the existing WWTP of K. Achaia, WWTP of University of Patras and the WWTP of Patras Industrial District, the WWTPs of Patras and Egio and two new WWTPs in the AkrataAigira and Sageika areas, can serve as poles for wastewater treatment for greater agglomerations as it is illustrated in Figure 1. The implementation of this scheme will expand coverage to $86-87 \%$ of the total population of the County, while the coverage required in compliance to the legislative framework is approximately $70 \%$.

The situation is different in the other sub-region of the County that covers mainly the inland. The population distribution is scattered in many small communities with low density and population that does not exceed 1000 people and therefore treatment schemes that are not based necessarily (there is no legal binding) to collection systems and typical WWTP can be applied.

However, the absence of legal binding does not imply environmental impediment of the region. Many areas in this sub-region face environmental problems due to uncontrolled or ineffective methods of wastewater discharge. In this case the most effective alternative for municipal wastewater management is the adoption of decentralized onsite treatment and disposal systems. These systems can be adjusted to the particular conditions of the community (with or without collecting system) and in a broad spectrum of demographic, hyrdogeological and climatological conditions. Moreover, as it is demonstrated by the preliminary cost analysis that follows, on-site systems represent not only an effective solution for small rural communities but also an economically efficient alternative.

Some of the small scale systems that have been evaluated are: Sequencing batch reactor (SBR), Biological filters (BF), Rotating biological contactors (RBCs), Oxidation ponds (OP), Typical septic tank (ST), Septic tank-absorption trench, 


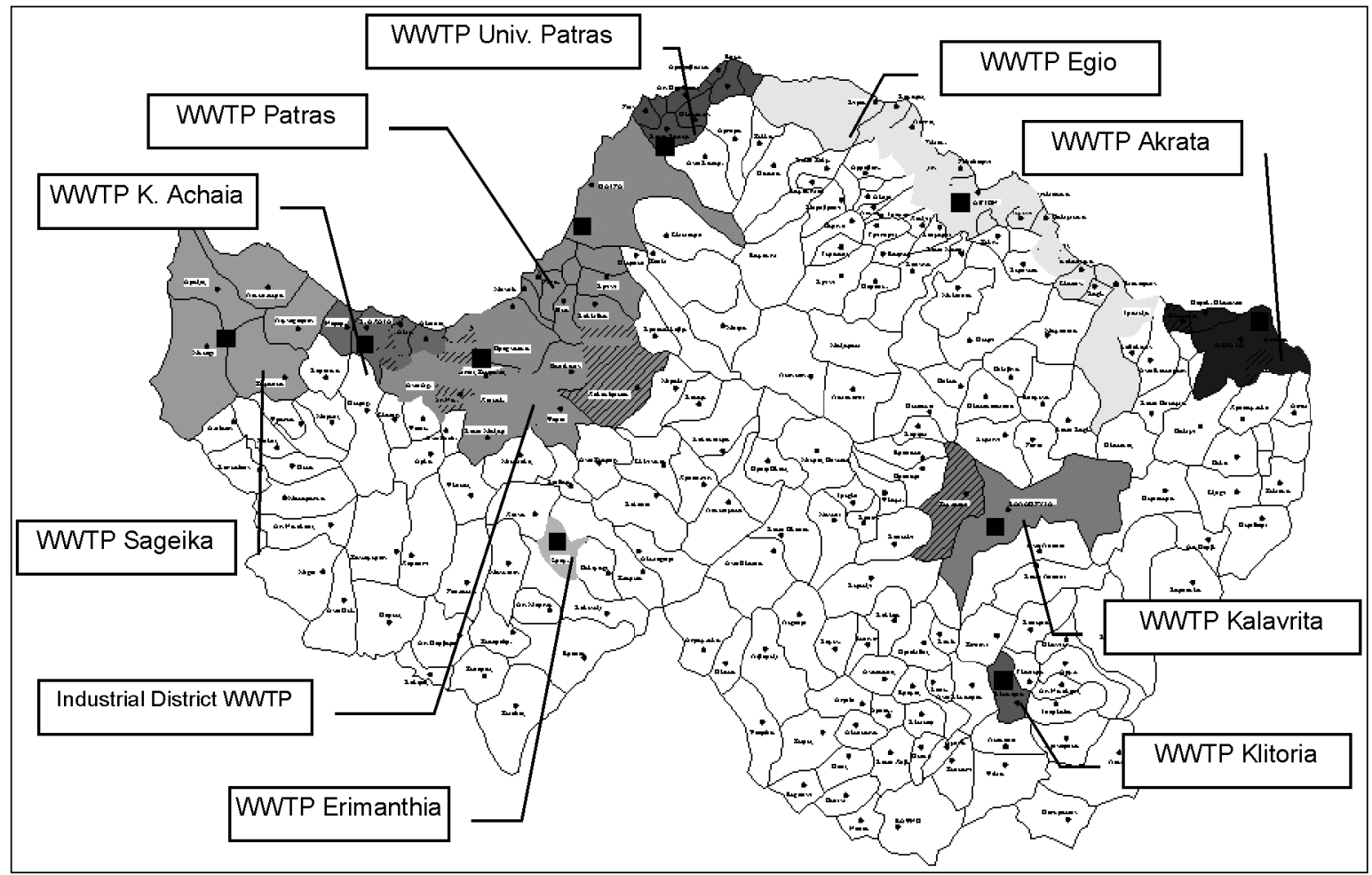

Figure 1. Central wastewater treatment plants and respective served areas

Septic tank-gravel filter-sand filter - absorption trenches, Constructed wetlands (CW) (Andreadakis and Christoulas, 1982; USEPA, 1980). Alternative treatment schemes compiled of the basic processes described above in relation to the requirement for wastewater collecting system, was comparatively evaluated on the basis of the achieved treatment level, the wastewater and sludge disposal possibilities (Table 3). Additionally, various parameters such as operational simplicity and land requirements were also accounted for.

Scheme 1. includes the collection of wastewater and treatment in a sequencing batch reactor (1A), biological filter (1B) or rotating biological contuctor (1C). The treated effluent particularly in the SBR can reach $10 \mathrm{mg} \mathrm{l-1}$ $\mathrm{BOD}_{5}$. Disposal of the treated effluent in rivers should be considered in relation to the sensitivity of the receiving body mainly because of the limited efficiency of the system in terms of nutrients removal. Wastewater reuse for restricted irrigation is an attractive alternative disposal route when certain conditions that will ensure safe reuse of wastewater can be met. As far as the produced sludge is concerned, it can be either used locally in agriculture after appropriate treatment or transferred to a larger WWTP for further treatment.

Scheme 2. includes the collection and treatment of wastewater in one of the aforementioned systems of scheme 1 , while additional treatment will be provided either in an aerobic pond (2A) or a filter (2B). Although disposal of the effluent in surface water bodies or subsurface disposal are still alternative disposal routes, the quality of the effluent achieved can justify even unrestricted irrigation.

Scheme 3. includes "primary" treatment of wastewater in individual septic tanks and collection and treatment of the overflows in an oxidation pond system. The disposal of the effluent can be done underground or in a surface water body. Alternatively the treated wastewater can be reused for restricted irrigation. Seepage should be regularly removed 
Table 3. Comparative representation of the alternative wastewater treatment and disposal schemes

\begin{tabular}{|c|c|c|c|c|c|c|c|c|c|c|c|c|c|}
\hline & \multicolumn{5}{|c|}{ Treatment system } & \multicolumn{5}{|c|}{ Wastewater disposal } & \multicolumn{3}{|c|}{ Sludge disposal } \\
\hline & ST & AT or & $\mathbf{C}$ & AS & OP & CW & FT & UI & RI & WD & SD & SE & $\mathbf{A U}$ \\
\hline & & $\mathbf{A P}$ & $\mathbf{S}$ & & & & & & & & & & \\
\hline Scheme 1A & - & - & $\checkmark$ & $\checkmark$ & - & - & - & - & $\checkmark$ & $\checkmark$ & $\checkmark$ & $\checkmark$ & $\checkmark$ \\
\hline Scheme 1B & - & - & $\checkmark$ & $\checkmark$ & - & - & - & $\checkmark$ & $\checkmark$ & $\checkmark$ & $\checkmark$ & $\checkmark$ & $\checkmark$ \\
\hline Scheme 1C & - & - & $\checkmark$ & $\checkmark$ & - & - & - & $\checkmark$ & $\checkmark$ & $\checkmark$ & $\checkmark$ & $\checkmark$ & - \\
\hline Scheme $2 \mathrm{~A}$ & - & - & $\checkmark$ & $\checkmark$ & $\checkmark$ & - & - & - & $\checkmark$ & $\checkmark$ & $\checkmark$ & $\checkmark$ & - \\
\hline Scheme 2B & - & - & $\checkmark$ & $\checkmark$ & - & - & $\checkmark$ & - & $\checkmark$ & $\checkmark$ & $\checkmark$ & $\checkmark$ & - \\
\hline Scheme 3 & $\checkmark$ & - & $\checkmark$ & - & $\checkmark$ & - & - & - & $\checkmark$ & $\checkmark$ & $\checkmark$ & $\checkmark$ & - \\
\hline Scheme 4 & $\checkmark$ & - & $\checkmark$ & - & - & $\checkmark$ & - & - & $\checkmark$ & $\checkmark$ & $\checkmark$ & $\checkmark$ & - \\
\hline Scheme 4A & $\checkmark$ & - & - & - & - & $\checkmark$ & - & - & $\checkmark$ & $\checkmark$ & $\checkmark$ & $\checkmark$ & - \\
\hline Scheme 5 & $\checkmark$ & - & - & - & - & - & - & - & - & - & - & $\checkmark$ & - \\
\hline Scheme 6 & $\checkmark$ & $\checkmark$ & - & - & - & - & - & - & - & - & - & $\checkmark$ & - \\
\hline Scheme 7 & $\checkmark$ & $\checkmark$ & - & - & - & - & $\checkmark$ & - & - & - & - & $\checkmark$ & - \\
\hline
\end{tabular}

ST: Septic tank, AT or AP: Absorption trench or pit, CS: Collecting system, AS: Activated sludge system,

OP: Oxidation pond, CW: Constructed wetland FT: Filtration UI: Unrestricted irrigation, RI: restricted irrigation,

WD: Surface water disposal, SD: Subsurface disposal, SE: Seepage, AU: Agricultural utilization

from the septic tanks and transferred to another WWTP for further treatment.

Scheme 4. includes "primary" treatment of wastewater in individual septic tanks and collection and treatment of the overflows in a constructed wetlands system. In this case the plants should be regularly removed out of the system and properly disposed. Seepage should also be regularly removed from the septic tanks and transferred to another WWTP for further treatment. Municipal wastewater, can alternatively inflow into the system without the septic tanks (4A); however the presence of the septic tanks ensures better operation.

Scheme 5. practically reflects the typical situation in communities that do not have wastewater collection system. It includes "primary" sedimentation in individual tanks, the overflows of which are infiltrated through the ground. Seepage are collected periodically and transferred for treatment in WWTP or disposed illegally on nearby water bodies.

Scheme 6. includes a typical septic tank - absorption pit or trench system.

Scheme 7. consists of a septic tank, gravel filter and absorption trenches. The wastewater goes through a treatment process that ensures high rate of suspended solids and organic load removal, producing effluent comparable to secondary treatment, especially when a sand filter is included. Effluent due to its improved quality can be disposed in high rate absorption trenches, while the settled solids in the septic tanks should be regularly removed.

During the selection of a small-scale wastewater treatment system the main features that have to be considered apart form the desired effluent quality are related to the great variations of flow and load of the influent in time. Thus, the most appropriate system is one that can effectively treat daily or seasonal loads, while at the same time these technologies have to be economically attractive and readily maintained.

From the previously mentioned systems, system 1A combines the production of high quality effluent (removal of BOD up to $90 \%$ and nitrogen up to $70-80 \%)$ at different operational conditions. The application of more simple systems with low maintenance and operational costs, which can achieve high removal efficiencies in terms of organic load (system 7), is related to the quality of the soil and the aquifer.

System 1A is practically related to a conventional activated sludge system and its construction cost can be estimated through the equation $\mathrm{K} 1=715,000 \times \Pi^{0,70}$, where $\mathrm{K} 1$ is the construction cost in drachmae (values 1999) and $\Pi$ is the population equivalent (Andreadakis and Chalkia, 1992). The cost of the collection system $(\mathrm{K})$ can be estimated for population densities less than 70 people/ha and 
Table 4. Assumptions for the comparison of annual costs of the alternative systems

\begin{tabular}{lcccc}
\hline & System 1A & Collection system & System 7 & System 5 \\
\hline Devaluation rate & $8 \%$ & $6 \%$ & $8 \%$ & - \\
Maintenance cost & $2 \%$ & $2 \%$ & $2 \%$ & 2000 GDR \\
Operational cost & $8 \%$ & $8 \%$ & - & - \\
Transport & - & - & 2000 GDR & 20000 GDR \\
\hline
\end{tabular}

cost of piping 50,000 GDR per meter of pipeline, from the equation $\mathrm{K}=50,000 \times(2.75 \times \mathrm{D}+60.58)$. For higher densities the required length of collection system is $250 \mathrm{mha}^{-1}$.

The construction cost of system 7 is estimated through the equation $\mathrm{K} 2=180,000 \times \Pi^{0,74}$, where $\mathrm{K} 2$ is the construction cost in drachmae (values 1999) and $\Pi$ is the population equivalent (Andreadakis and Christoulas, 1982). The economic comparison of the systems is based on the following assumptions presented in Table 4.

Figure 2 presents the costs $\mathrm{K} 1$ and $\mathrm{K}$ for each area as compared to the cost of decentralized on site treatment system K2. The selection of on site treatment system (particularly system) is financially attractive considering the high cost of collection systems. The annual cost per capita related to the population density, for the three alternative systems, is presented in Figure 3, showing that the application of on site systems is more economical as compared to the present situation and the adoption of activated sludge systems.

From this initial evaluation of the alternative wastewater treatment systems for the inland areas, the adoption of on site treatment and disposal systems is the main proposal, although a case-by-case study should be conducted to determine the best solution for each area.

\section{CONCLUSIONS}

The most important conclusions of the study are summarized as follows:

- As of 2000, wastewater collection systems covered almost $50 \%$ of the total population, mainly on the coastal communities, although only $2 \%$ of the population was receiving adequate treatment in WWTP. The rest of the population used typical septic tanks.

- In compliance to the EU Directive 91/271, it is estimated that collecting systems and treatment should expand to at least $70 \%$ of the total population. However, due to the expanding touristic activity, the limited availability of land, environmental considerations, and favorable population characteristics (high density, relatively large communities) and morphological and socioeconomical conditions, it is proposed that coverage can reach

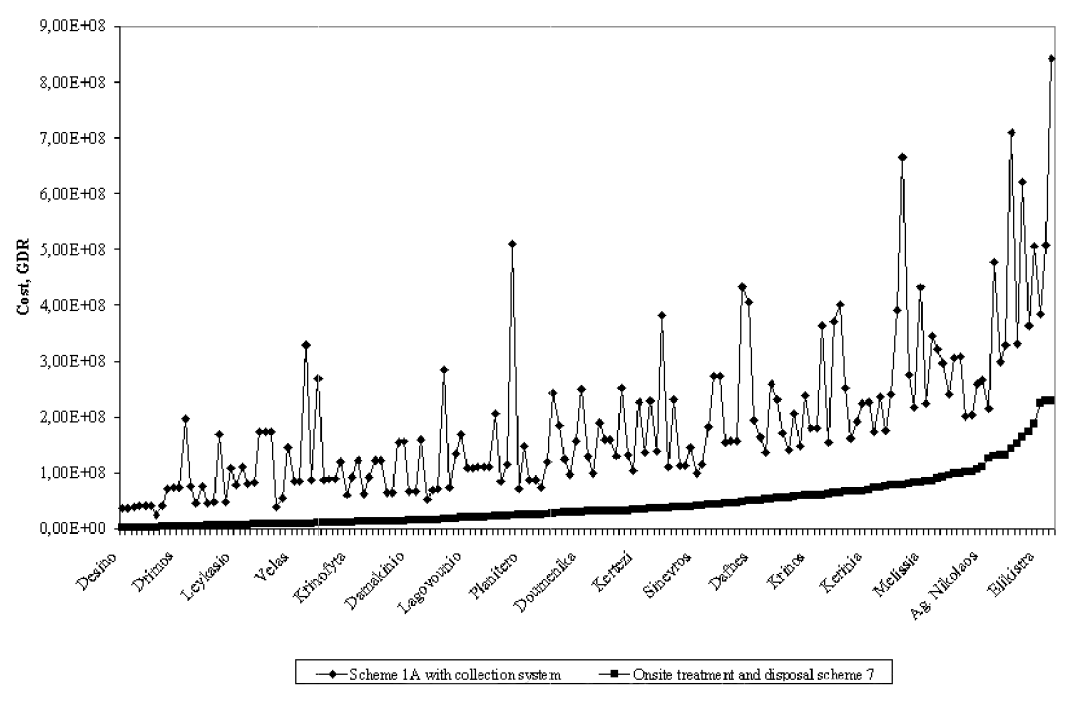

Figure 2. Construction cost of alternative wastewater treatment schemes for the small rural communities of the County 


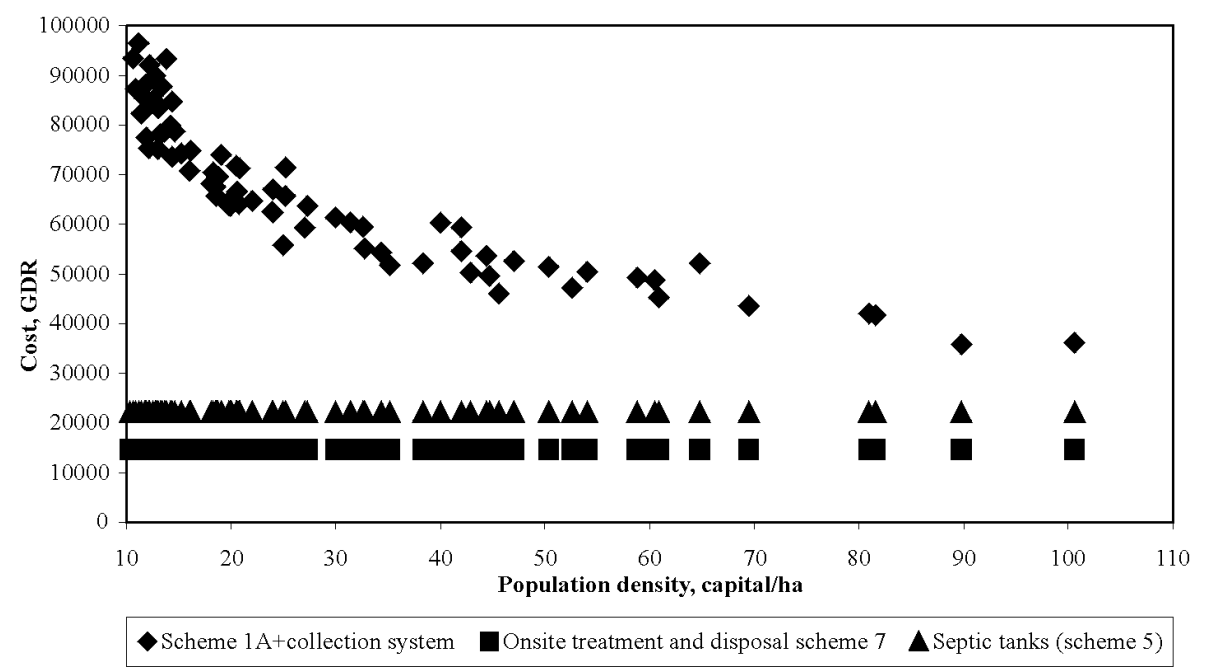

Figure 3. Total annualised cost per capital of alternative treatment schemes

$85 \%$ of the total population.

- As for the rest of the County population $(15 \%)$, decentralized on site wastewater treat- ment and disposal schemes were proved to be the most technically effective and economically efficient alternative.

\section{REFERENCES}

European Council Directive (91/271/EEC) (1991), Concerning urban wastewater treatment, Official Journal of the European Communities, 1991,L135/40, p.30

Ministerial Decree (5673/400/97) (1997), Concerning urban wastewater treatment, Official Journal of the Greek Government, 1997, (in Greek)

National Law (2539/97). (1997), Composition of Local Authorities, Official Journal of the Greek Government, 1997, A244/4-12-97, (in Greek)

Zacharias I., Ferentinos G. and Kastanos N. (1995), Environmental problems from the setting of Patras sewage pipe, Proceedings of the $4^{\text {th }}$ Conference on Environmental Science and Technology, University of Aegean, Dept. of Environmental Studies, Molyvos, Lesvos Greece.

Lazarou, A., Katsara, A., Theofilopoulos, G., Jeftic, L., Kyriazopoulou, I. (1999), Coordinated monitoring of the quality of the marine and coastal environment of Greece, Proceedings of $3^{\text {rd }}$ International Exhibition and Conference - HELECO '99, Thessaloniki, Greece.

Rozos, D. (1989), Technikogeological conditions in Achaia County, Ph.D., Geology Dept., University of Patras, Patras (in Greek).

Krestenitis, G., Daskalaki, P., Diamantopoulou, P. (1999), Water supply in Rio municipality with a 30 year projection, One day seminar: Management of water resources and protection of rivers and streams of Rio municipality, Patras, Rio Municipality, University of Patras (in Greek).

Andreadakis, A.D, Christoulas D.G. (1982), On Site Filtration and Subsurface Disposal of Domestic Sewage, Environmental Technology Letters, 3, 69-74.

US EPA, (1980), Design Manual "Onsite Wastewater Treatment and Disposal Systems", EPA 625/1-80-012.

Andreadakis A.D., Chalkia A. (1992), Cost estimation of wastewater treatment plants through statistical analysis of data from Greek WWTP, Proceedings of the $5^{\text {th }}$ Conference of the Greek Hydrotechnical Union, Larisa, Greece (in Greek) 